\title{
The norite-mangerite relationships in the Bjerkreim-Sokndal layered lopolith (southwest Norway)
}

\author{
J.C. DUCHESNE ${ }^{1}$, B. DENOISEUX ${ }^{1}$ and J. HERTOGEN ${ }^{2}$ \\ ${ }^{1}$ Geology, Petrology and Geochemistry, University of Liège, B-4000 Sart Tilman (Belgium) \\ ${ }^{2}$ Physico-chemical Geology, University of Leuven, B-3030 Leuven (Belgium)
}

\section{LITHOS}

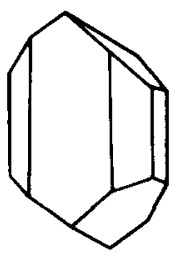

Duchesne, J.C., Denoiseux, B. and Hertogen, J., 1987. The norite-mangerite relationships in the Bjerkreim-Sokndal layered lopolith (southwest Norway). Lithos, 20:1-17.

The Transition Zone between the anorthositic-noritic rhythmic units and the mangeritic unit of the Bjerkreim-Sokndal layered lopolith (southwest Norway) is characterized by thick layers of ultramafic rock (UML), interleaved with norites in the lower part and mangerites in the upper part. In the latter rocks large mesoperthite crystals occur in a fine-grained groundmass (porphyritic texture). Rapid variations in chemical composition are shown by the mafic minerals, especially by olivine $\left(\mathrm{Fo}_{50}\right.$ to $\left.\mathrm{Fo}_{19}\right)$ and by Ti-magnetite $\left(10-19 \% \mathrm{TiO}_{2}\right)$. The whole-rock composition of the UML does not change in the upper part of the Transition Zone, and the $\mathrm{Fe} /(\mathrm{Fe}+\mathrm{Mg}$ ) ratio of the mangerites remains constant (Bowen trend). Formation of the UML through liquid immiscibility is rejected because: (1) the liquidus minerals are not always identical in the Fe-rich and associated silica-rich rocks; (2) the distribution of $\mathrm{P}_{2} \mathrm{O}_{5}$, $\mathrm{REE}$ and $\mathrm{Ba}$ between associated rocks are not in agreement with experimental data; (3) the major elements vary along parallel trends in the Creigh diagram. Cumulative processes and adcumulus growth can best explain the UML, oscillatory nucleation can account for the norites, and flotation of mesoperthite is plausible in the mangerites, where accumulation of feldspar is evidenced by a strong positive Eu anomaly and porphyritic textures. The mangeritic unit of the lopolith is interpreted as a flotation cumulate at the toof of the magma chamber. The residual liquids of the Bjerkreim-Sokndal differentiation were either trapped in the mangerites, or expelled in the form of dykes, or were mixed with quartz mangeritic liquids above the intrusion.

(Received Septem ber 17, 1985; accepted after revision May 30, 1986)

\section{Introduction}

The association of massif-type anorthosites with acidic rocks, a key feature of the deep crust, has long been controversial. A first model, originally proposed by Buddington (1972) and further developed, e.g. by Martignole (1974) and Emslie (1978), considers the acidic rocks (mangerites and quartz mangerites) to be coeval with the anorthosites, but to derive from different magmas. The alternative explanation, introduced by P. Michot (1956) and elaborated by Philpotts (1966) and many others, favours the comagmatic character of anorthosites and quartz mangerites. Both rock types are interpreted as the end-members of a continuous series comprising norites, monzonorites (jotunites) and mangerites as intermediate members. P. Michot's model was based on a detailed study of the Bjerkreim-Sokndal layered lopolith (BKSK), in the Rogaland anorthositic province (SW Norway). This intrusive body displays a series of cumulates, starting with anorthosites on the exposed floor and grading - in perfect geometrical conformity - into quartz mangerites at the top (P. Michot, 1960, 1965). However, P. Michot's model has been questioned on the basis of isotopic and trace element 
data (J. Michot and Pasteels, 1969; Pasteels et al., 1970, 1979; Duchesne and Demaiffe, 1978; Demaiffe et al., 1979; Wielens et al., 1981). Progressive contamination by supracrustal material during the late stages of magmatic differentiation was invoked to account for the higher initial $\mathrm{Sr}$ isotopic ratio in the acidic rocks than in the anorthositic-noritic part of the massif. Recent work by Wiebe (1984) suggests complex commingling of magmas of various origin to account for the upper part of the massif.

Since the purely co-magmatic character of the BKSK sequence was questioned, it became of interest to investigate the rocks of the transition between norites and mangerites. Moreover, recent work emphasized the role of liquid-liquid immiscibility in the evolution of $\mathrm{Fe}, \mathrm{Ti}, \mathrm{P}$-rich magmas (McBirney, 1975; Roedder, 1979) that could possibly have played a role in producing transition rocks. Generation of complementary acidic and ferrodioritic/jotunitic rocks through immiscibility has also been suggested by Wiebe (1979) and Philpotts (1981) on the basis of field and petrographic evidence.

It is the purpose of the present paper to provide petrographic and geochemical data on the transition rocks of BKSK and to evaluate how these data constrain the differentiation mechanism of the lopolith.

\section{The Bjerkreim-Sokndal massif}

BKSK extends over more than $40 \mathrm{~km}$ from Bjerkreim to Sokndal and shows an eastward digitation towards Mydland (Fig. 1). A comprehensive description of the body has been given by P. Michot (1960, $1965,1969)$. The magma intruded at the end of the Sveconorwegian orogeny, around 930-950 Ma (Pasteels et al., 1979). The body was deformed during the solidification of its lower part. Numerous features, e.g. a protoclastic granulation of the plagioclase, indicate that the deformation took place when the material was still partly liquid.

The lower part of the lopolith, well developed in the northern part of the body, comprises anorthosites, leuconorites and norites in five megarhythmic units (rhythms I to V of P. Michot), each one starting with anorthosite or leuconorite at the base and grading upward into more mafic-rich rocks. Textures typical of layered igneous rocks (Irvine,
1982) are well developed in the lower part of the body (planar lamination, uniform, intermittent or modally graded layering). The upper part of the body consists of acidic rocks, essentially made up of mangerites (hypersthene mesoperthite monzonite), and overlain by quartz mangerites (hypersthene or fayalite mesoperthite quartz monzonite). The texture is more massive than in the lower part, an ill-defined lamination being the only common character with the rocks from the lower part. In between the two parts a thin Transition Zone of - overall monzonoritic (jotunitic) character is observed.

The overall mineral variation in the lopolith was described by P. Michot (1965). Cryptic layering is conspicuous in the major and trace element variations of the solid solution minerals (Duchesne, 1972a, b, 1978). Neglecting the recurrent variations introduced by the five megarhythmic units of the lower part, the following sequence of mineral assemblages can be reconstructed. Plagioclase (unzoned; $\mathrm{An}_{50}-\mathrm{An}_{43}$ ), orthopyroxene (starting with $\mathrm{En}_{75}$ ) and oxide minerals (first hemo-ilmenite alone, then accompanied by magnetite) form the association of the anorthosites, leuconorites and the basis of the norites. A magnesian olivine $\left(\mathrm{Fo}_{70}\right)$ briefly appears in a unique leuconoritic layer. Higher in the norites plagioclase becomes more albitic $\left(\mathrm{An}_{45}\right.$ $\mathrm{An}_{40}$ ) and clinopyroxene as well as apatite enter as additional cumulate minerals. In the upper part of the norites potassium feldspar first appears as antiperthite in the plagioclase, then as an interstitial mineral. Olivine $\left(\mathrm{Fo}_{50}-\mathrm{Fo}_{20}\right)$ re-appears in the Transition Zone. The abundance of mafic minerals culminates in the Transition Zone, and decreases abruptly in the mangerites. The $\mathrm{Fe} /(\mathrm{Fe}+\mathrm{Mg})$ ratio of the two pyroxenes increases progressively throughout the sequence, inverted pigeonite appearing in the upper norites (Duchesne, 1972b). The hematite content of ilmenite decreases upwards and the $\mathrm{Ti}$ and $\mathrm{Al}$ contents of the magnetite reaches a maximum in the Transition Zone (Duchesne, 1972a). Typical mangerite contains mesoperthite and interstitial fayalite $\left(\mathrm{Fo}_{8}\right)$, clinopyroxene $\left(\mathrm{Ca}_{38} \mathrm{Fe}_{47} \mathrm{Mg}_{15}\right)$ and some orthopyroxene $\left(\mathrm{En}_{18} \mathrm{Fs}_{76} \mathrm{Wo}_{6}\right)$. The two $\mathrm{Fe}-\mathrm{Ti}$ oxides, apatite and zircon are accessories. The upper part of the lopolith comprises several types of quartz-bearing acidic rocks (P. Michot, 1960; Hermans et al., 1975; Demaiffe et al., 1979; Rietmeijer, 1979; Wiebe, 1984). In contrast to 


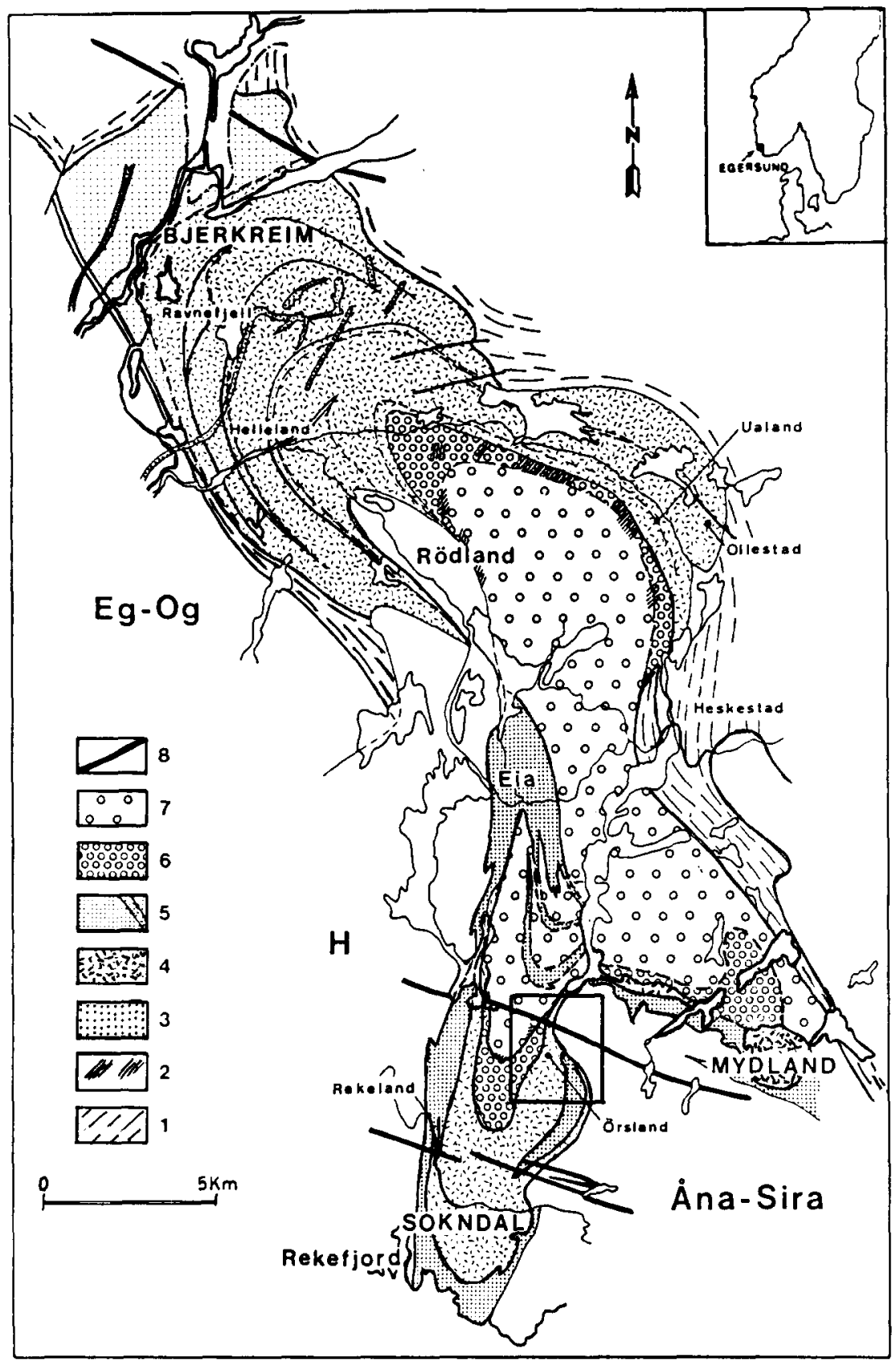

Fig. 1. The Bjerkreim-Sokndal layered lopolith (Rogaland, S. Norway) (after P. Michot, 1960; J. Michot and Michot, 1969). Legend: 1 = metamorphic envelope; $2=$ xenolithic septum; $3=$ anorthosites; $4=$ leuconorites and norites; $5=$ monzonorites and related rocks of Eia-Rekefjord intrusion; $6=$ mangerites; $7=$ quartz mangerites; $E g-O g=$ Egersund-Ogna anorthositic massif; $H=$ Amdal-Helleren-Rödland anorthositic massif; Ana-Sira = Åna-Sira anorthositic massif.

the lower part of the massif, a detailed stratigraphy could not be worked out. A discontinuous zone of xenolithic rocks girdles the contact between the mangerites and the quartz mangerites (Fig. 1) ["septum xénolitique" of P. Michot (1960); Hermans et al. (1975); Wiebe (1984)]. This makes it difficult to establish whether the quartz mangerites have a partly or totally different origin from that of the mangerites. A detailed discussion of the quartz mangerites is outside the scope of the present paper. 
It is sufficient to mention that the most important varieties are a fayalite-bearing quartz mangerite and a hypersthene quartz monzonite.

The mineralogical evolution of BKSK broadly parallels classical evolutions in the intermediate and upper parts of tholeitic layered intrusions (see Wager and Brown, 1968). Trace element geochemistry has confirmed that fractional crystallization is the main differentiation mechanism in the lower part of the massif and that adcumulus growth can account for the formation of the layered rocks (Duchesne, 1978; Roelandts and Duchesne, 1979). The nature of the parental magma is not known from direct evidence but a monzonoritic composition is plausible because it accounts for the relatively high proportion of acidic relative to basic rocks (P. Michot, 1965). Such a composition also fits trace element modeling (Duchesne, 1978; Duchesne and Demaiffe, 1978; Roelandts and Duchesne, 1979; Duchesne et al., 1985).

The central acidic part of the massif stands out in the landscape, whereas the noritic rocks - readily weathered and covered with vegetation - occupy the topographic lows. The Transition Zone can be traced all along the cliffs of mangeritic rocks. The nature of the outcrops makes reconstruction of the detailed stratigraphic succession within the Transition Zone rather difficult, except in the vicinity of Bakka-Örsland, on which this study is focused.

\section{The Bakka-Orsland area}

Bakka-Orsland is situated on the eastern flank of the Sokndal lobe of the lopolith (Fig. 1). North of that region the norites thin out in a gorge between the Ana-Sira anorthositic massif and the acidic central unit of the lopolith (Fig. 2). Several sections in the transition from the norites to the acidic rocks can be observed near Örsland. The norites, usually rather homogeneous, show igneous lamination, slight variations in the mafic index from layer to layer or fine-scale irregular bandings. The Transition Zone, 50 to $80 \mathrm{~m}$ thick, with individual layers from 0.5 to $4 \mathrm{~m}$ thick, is characterized by a succession of ultramafic layers (UML) interleaved with noritic layers in the lower part and with mangeritic layers in the upper part. It has thus been divided into a lower noritic Transition Zone and an upper mangeritic Transition Zone. The individual UML

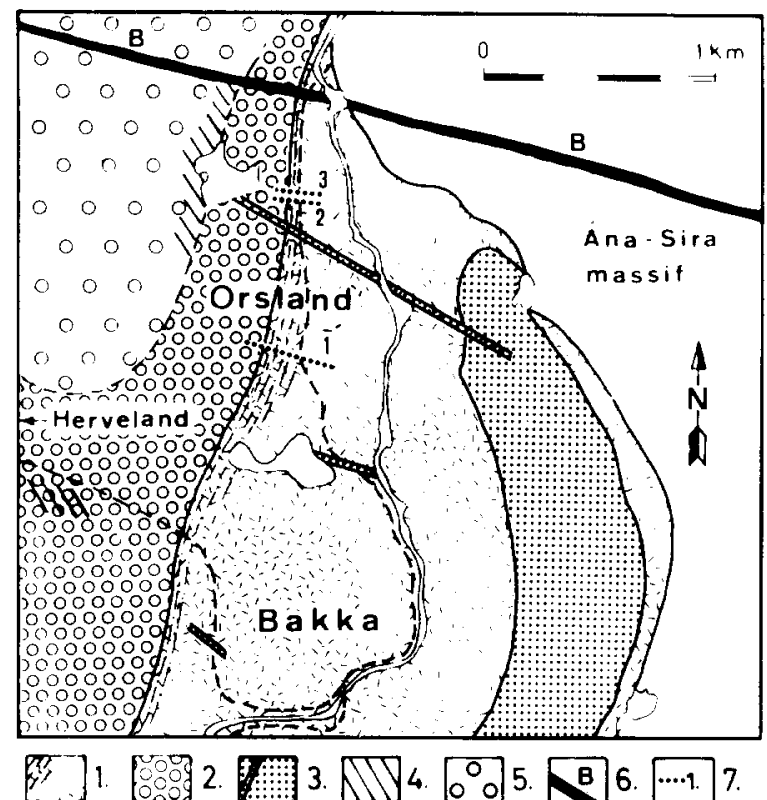

Fig. 2. Geological sketch map of the Bakka-Örsland area (partly after P. Michot, 1960; Krause and Pedall, 1980). Legend: $l=$ norites and, in the upper part, Transition Zone; 2 = mangeritic unit; 3 = fine-grained monzonites and related rocks occurring in an appendix to the Eia-Rekefjord intrusion or as dykes; $4=$ zone of concentration of xenolithic inclusions; $5=$ quartz mangeritic unit; $6=$ dolerite dyke; $7=$ main outcrops and sections.

do not appear to extend laterally over more than a few tens of meters and rapid variations in thickness have been traced locally. There is no gradation between the UML and the overlying more felsic layers. The layers are generally homogeneous, though some faint banding has been observed in one case. The mangeritic unit is made up of massive leucocratic rocks with ill-defined lamination. The contact with the quartz mangerites is crowded by inclusions of quartzo-feldspathic to noritic gneisses of various grain sizes. Rounded, sharply bounded, fine-grained inclusions [pillow-like inclusions of Wiebe (1984)] of monzonoritic to monzonitic composition are frequent in the mangerites and quartz mangerites. Dykes of fine-grained quartz monzonite, which cut across the norites, are related to the nearby EiaRekefjord intrusion (Fig. 1) and its appendix, the cigar-shaped body (Fig. 2) which lies east of Bakka-Örsland (P. Michot, 1960, 1965). One dyke - called here the Örsland dyke - appears to be later than the other ones, because it cuts across the mangerites and contains inclusions derived from the cigar-shaped body. 


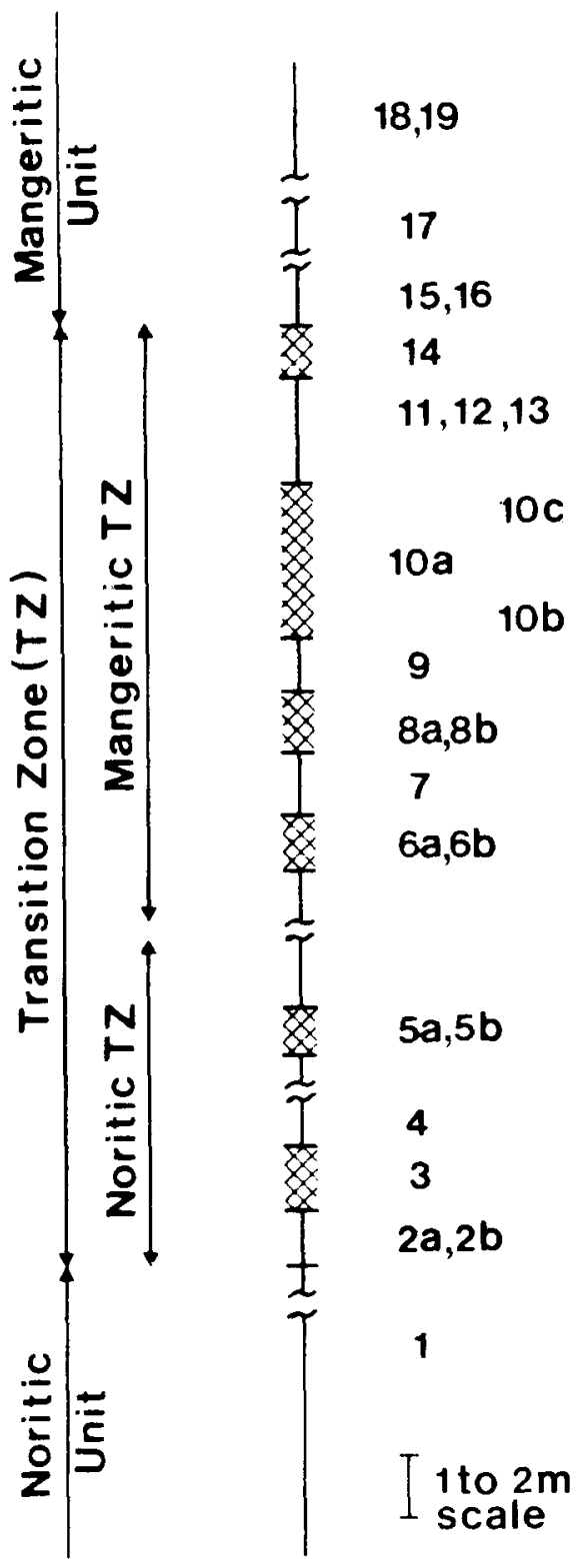

Fig. 3. Stratigraphic sequence of rocks and position of the samples analysed in Tables 1 and 2. Cross-hatched sections represent the ultramafic layers (UML). Each gap in the section is of the order of a few meters.

A complete "stratigraphic" profile across the Transition Zone is given in Fig. 3. It is mainly based on three sections near Örsland (numbered 1 to 3 in Fig. 2) and on the road-cut to Herveland. In each section, the same topological succession of rocks and cryptic layering has been observed. No lateral compositional variation such as those described by Wilson and Larsen (1985) in the Fongen-Hyllingen complex is apparent.

\section{Petrography and mineral chemistry}

Three main types of rocks can be distinguished in the Transition Zone: the norites, the ultramafic layers (UML) and the mangerites.

The norites. These are petrographically similar to the norites from the upper part of the anorthositic-noritic phase of the lopolith. As already mentioned they show igneous lamination and banding. Their petrographic structure can be interpreted in terms of a cumulate hypothesis. Though the microtexture is somewhat blurred by protoclastic granulation of plagioclase, orientation of the less deformed cumulate minerals with their $c$-axes parallel to the lamination plane can be recognized. The plagioclase $\left(\mathrm{An}_{40}\right.$, unzoned) is slightly antiperthitic. Some K-feldspar is interstitial to the cumulus minerals (the normative orthoclase content approaches $10 \%$ relative to the plagioclase content). Orthopyroxene (opx), first prismatic and typically a cumulate mineral, grades upwards into a poikilitic inverted pigeonite. Clinopyroxene (cpx) is present in lesser amount than orthopyroxene. Euhedral apatite occurs partly associated with the interstitial Fe-Ti oxides, and partly as independent grains. Fe-Ti oxides fill the interstices between all cumulus minerals, including the granulated plagioclase, and must have completed their growth after the protoclasis and the crystallization of all other minerals.

The ultramafic layers. In the noritic Transition Zone they consist of euhedral olivine $\left(\mathrm{Fo}_{50}\right.$ to $\left.\mathrm{Fo}_{44}\right)$ surrounded by relatively minor amounts of cpx and large amounts of interstitial opaques (up to $50 \mathrm{wt} . \%$ of the rock) (see Table 6). The latter are homogeneous ilmenite and cloth-textured Ti-magnetite with Al-spinel exsolutions (see Duchesne, $1970,1972 \mathrm{a}$ ). Apatite (up to $10 \mathrm{wt} . \%$ ) occurs as prismatic crystals between the olivines and also in the opaques. Small quantities of interstitial plagioclase are occasionally present. It must be emphasized that olivine, which is a dominant mineral in the UML, has never been found - despite a careful search - in the associated noritic layers, where the only Fe-Mg silicates are the pyroxenes. In the UML of the mangeritic Transition Zone, the amount of cpx increases compared to the UML of the noritic Transition Zone (see Table 6). Olivine and cpx show interlobate grain boundaries, suggesting simultaneous crystallization. Compared to the noritic Transition Zone the oxide minerals are less abundant (ca. $35 \mathrm{wt} . \%$ ) and richer in Ti-magnetite. The latter is devoid of Al-spinel exsolutions. Apatite is also less abundant (2-4 wt.\%) than in the noritic Transition Zone and occurs as minute inclusions in cpx. In rare cases (sample 10a, see Table 6) some feldspar is present as a fine-grained mosaic of plagioclase and K-feldspar, locally surrounding larger mesoperthitic grains and always occurring in the interstices of the mafics. Traces of brownish amphibole and biotite are occasionally observed.

The mangeritic rocks. The porphyritic appearance of the mangeritic rocks is due to large mesoperthites of irregular shape $(0.2-0.7 \mathrm{~cm})$ dispersed in a fine-grained groundmass 
$(200-500 \mu \mathrm{m})$. The groundmass is an equigranular mosaic of plagioclase and microperthitic K-feldspar in which large olivines are usually interstitial, except for some smaller euhedral grains the size of the feldspars. Cpx is molding the olivine. The oxide minerals also display an interstitial habit relative to all other minerals. Apatite is present in the mosaic with the average grain size of the rest of the groundmass. Some grains, however, show an anomalously larger size. The relative proportions of mesoperthitic phenocrysts and groundmass varies from sample to sample [colour index between 42 (sample No. 9) and 21 (samples Nos. 7 and 16)]. In the typical mangerites lying above the Transition Zone (e.g., sample No. 19), the amount of groundmass is reduced to a negligible value. Very little or no deformation of the minerals is observed in the mangeritic Transition Zone and upwards, in contrast to the subjacent noritic levels.

\section{Mineral chemistry}

Olivine (Table 3 and Fig. 4) shows a conspicuous and rapid $\mathrm{Fe}$-enrichment trend, from $\mathrm{Fo}_{50}$ at the base of the Transition Zone to $\mathrm{Fo}_{19}$ at the top. The same $\mathrm{Fe}$ enrichment characterizes the cpx evolution (Table 4). The data confirm preliminary results of Duchesne (1972b) on the evolution of the entire intrusion. Ilmenite is close to the pure end-member $\mathrm{FeTiO}_{3}$ and Ti-magnetite falls near the $\mathrm{FeTiO}_{3}$ $\mathrm{Fe}_{3} \mathrm{O}_{4}$ join (Table 5). Evidence has been cited in favour of an original ulvöspinel-magnetite solid solution at solidus temperature for the Ti-magnetite and subsequent subsolidus oxidation-exsolution of the ulvöspinel above and/or below the solvus (Duchesne, 1970, 1972b). Subsolidus re-adjustment which affected the oxide mineral compositions in the mangerites is probably of lesser extent in the UML, where no reaction rim between ilmenite and magnetite could be observed. Application of the Buddington and Lindsley (1964) geothermometer and oxygen fugacity barometer following Powell and Powell (1977) gives $675 \pm 35^{\circ} \mathrm{C}$ and $\log \left[f_{\mathrm{O}_{2}}\right.$ $(\mathrm{atm}).]=-19.2 \pm 0.3$, that is one order of magnitude less than the FMQ buffer. The chemical evolution of the Ti-magnetite of the UML shows a twofold increase in $\mathrm{TiO}_{2}$ content from the base of the Transition Zone to the top.

\section{Geochemical data}

Whole-rock major elements (Tables 1 and 2) in the $A F M$ diagram (Fig. 5) show that the UML form a tight cluster along the $F M$ join. The UML associated with mangerites are slightly but significantly richer in the $F$ component $\left[\mathrm{FeO}^{*} /\left(\mathrm{FeO}^{*}+\right.\right.$ $\mathrm{MgO})=0.85]$ than those from the noritic part of the Transition Zone (0.71). The norites associated with their UML also form a distinct cluster slightly lower in $F / M$ ratio than the mangerites and associated UML. The mangerites plot not far from a tie-line connecting the associated $\mathrm{UML}$ and the $A$-apex, thus indicating a virtually constant $F / M$ ratio in the Transition Zone and upwards in the mangeritic unit. It is worth noting that the increase in amount of feldspar does not match the stratigraphic order, e.g. No. 7 which has a high alkali content, is the lowermost mangeritic layer of the Transition Zone.

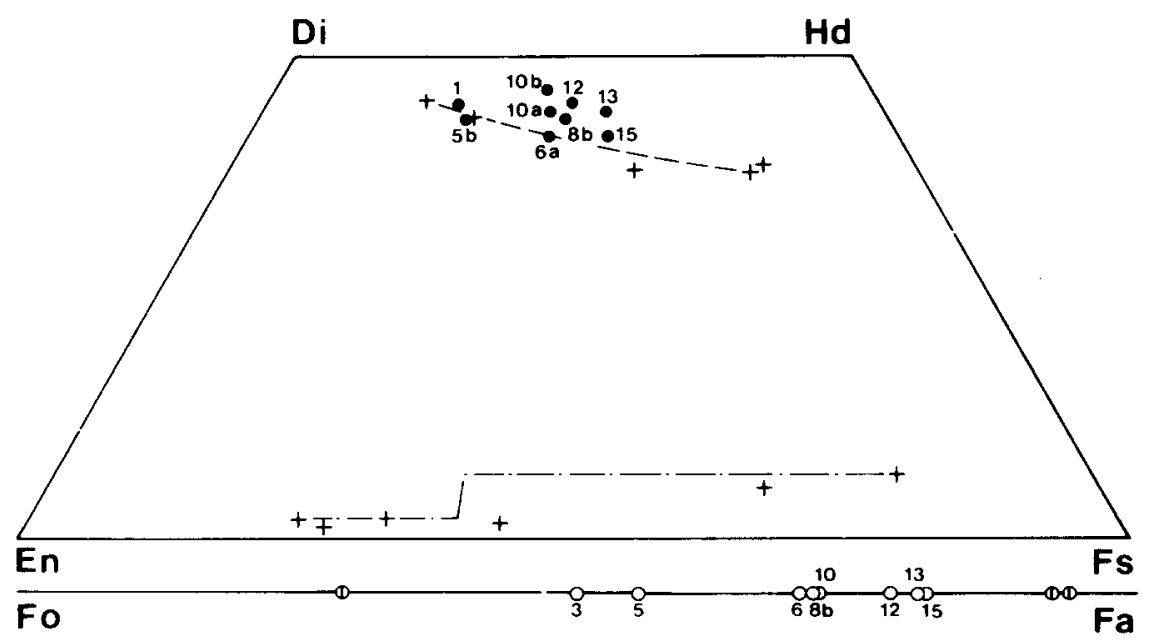

Fig. 4. Plots of olivine and pyroxene composition: open circles $=$ data in $T a b l e ~ 3$; solid circles $=$ data in Table 4 ; divided circles and crosses $=$ olivine and pyroxene compositions from Duchesne (1972b). 
TABLE 1

Whole-rock chemical analyses

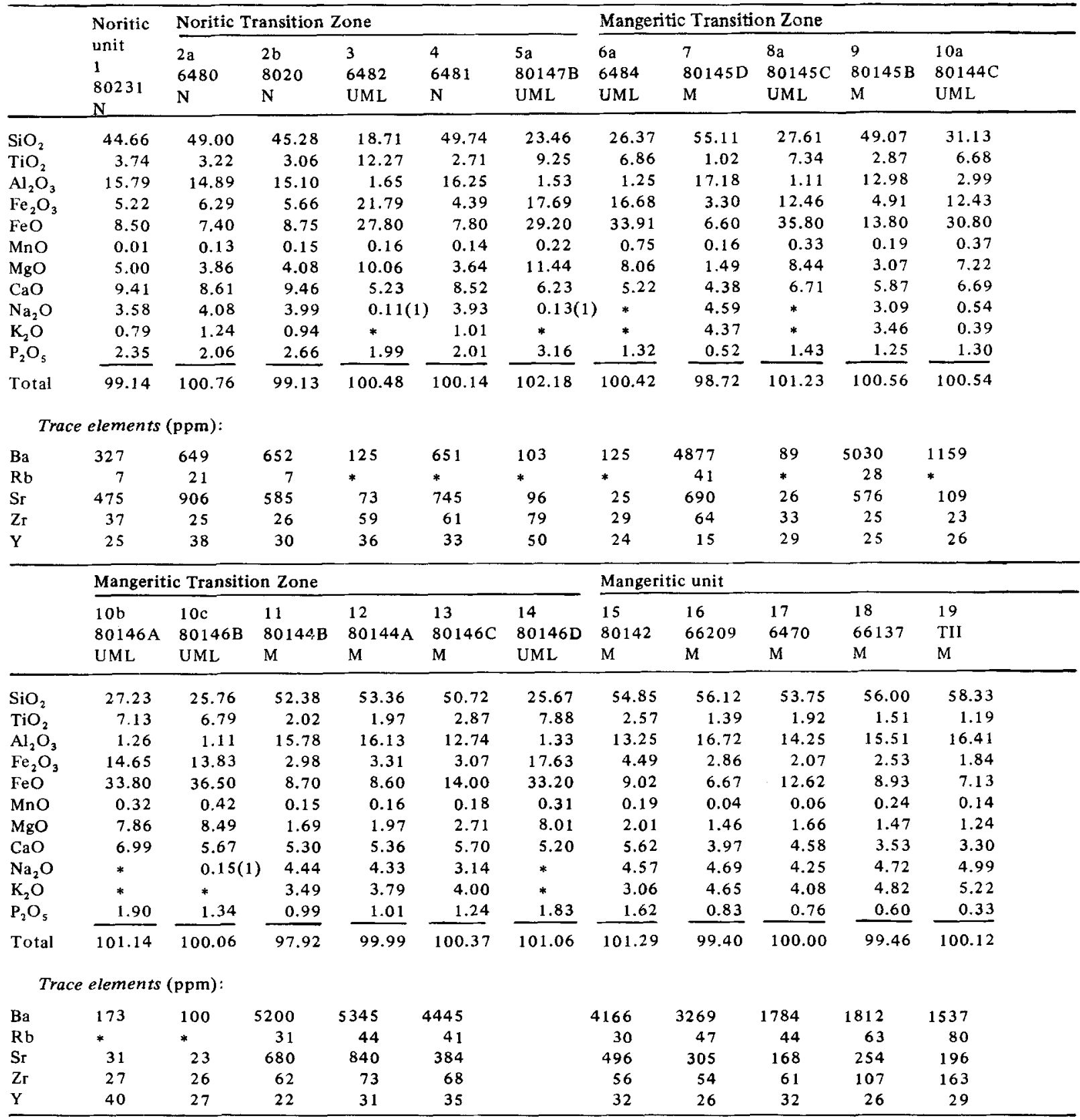

$\mathrm{N}=$ noritic layer; $\mathrm{UML}=$ ultramafic layer; $\mathrm{M}=$ mangeritic layer; $(1)=$ determined by $\mathrm{NAA} ; *$ = below detection limit.

Location of the samples: $1=$ path to Örsland farm; $2 a, b, 3,4=$ section 1 in Fig. 2 , along the path, south of Örsland; 5a, 6a, $b$, $8 \mathrm{~b}, 10 \mathrm{~b}, \mathrm{c}, 13,14=$ section 2 in Fig. 2, north of Orsland; $5 \mathrm{~b}, 7,8 \mathrm{a}, 9,10 \mathrm{a}, 11,12,15=$ section 3 in Fig. $2 ; 16=$ Slatten, on the road from Bakka school to Herveland; $17,18,19=$ same road, at point $h$ of excursion III in P. Michot's (1960) guide book. 
TABLE 2

Whole-rock trace element contents

\begin{tabular}{|c|c|c|c|c|c|c|c|}
\hline & \multicolumn{3}{|c|}{ Noritic Transition Zone } & \multicolumn{4}{|c|}{ Mangeritic Transition Zone } \\
\hline & $\begin{array}{l}2 \mathrm{~b} \\
8020 \\
\mathrm{~N}\end{array}$ & $\begin{array}{l}3 \\
6482 \\
\text { UML }\end{array}$ & $\begin{array}{l}5 a \\
80147 B \\
\text { UML }\end{array}$ & $\begin{array}{l}10 a \\
80144 C \\
\text { UML }\end{array}$ & $\begin{array}{l}11 \\
80144 B \\
M\end{array}$ & $\begin{array}{l}10 \mathrm{c} \\
80146 \mathrm{~B} \\
\mathrm{UML}\end{array}$ & $\begin{array}{l}13 \\
80146 \mathrm{C} \\
M\end{array}$ \\
\hline $\mathrm{La}$ & 35.3 & 25.5 & 32.5 & 10.1 & 22.2 & 12.7 & 25.2 \\
\hline $\mathrm{Ce}$ & 94 & 73 & 91 & 31.1 & 55 & 38.6 & 65 \\
\hline Nd & 71 & 60 & 76 & 31 & 35 & 37 & 47 \\
\hline Sm & 15.4 & 12.9 & 16.4 & 7.68 & 8.3 & 8.2 & 10.9 \\
\hline Eu & 5.3 & 3.29 & 4.21 & 2.99 & 7.43 & 2.33 & 6.47 \\
\hline $\mathrm{Gd}$ & & & & & & 8.4 & 10.4 \\
\hline $\mathrm{Tb}$ & 2.01 & 1.62 & 2.09 & 1.04 & 1.10 & 1.11 & 1.45 \\
\hline $\mathrm{Yb}$ & 2.4 & 1.85 & 2.33 & 1.45 & 1.55 & 1.45 & 2.21 \\
\hline $\mathbf{L u}$ & 0.39 & 0.28 & 0.34 & 0.25 & 0.27 & 0.27 & 0.40 \\
\hline $\mathrm{Sc}$ & 22.0 & 35.2 & 34.1 & 98 & 29.2 & 85 & 48.8 \\
\hline $\mathrm{Cr}$ & $<4$ & 6 & 4 & $<6$ & $<4$ & 7 & $<3$ \\
\hline Co & 24.0 & 109 & 115 & 40.2 & 12.0 & 51.6 & 17.3 \\
\hline $\mathrm{Hf}$ & 1.5 & 1.5 & 1.9 & $<0.5$ & 1.9 & 0.73 & 1.8 \\
\hline $\mathrm{Ta}$ & 0.35 & 1.05 & 0.93 & 0.25 & 0.48 & 0.32 & 0.37 \\
\hline Th & 2.0 & 1.0 & 1.0 & $<0.6$ & 2.0 & $<0.3$ & 3.3 \\
\hline $\mathrm{U}$ & 0.4 & 0.3 & 0.4 & $<0.3$ & 0.6 & $<0.2$ & 0.9 \\
\hline
\end{tabular}

$\mathrm{N}=$ noritic layer $; \mathrm{UML}=$ ultramafic layer $\mathbf{M}=$ mangeritic layer.

TABLE 3

Chemical composition of olivines (microprobe analyses)

\begin{tabular}{|c|c|c|c|c|c|c|c|c|c|c|}
\hline & $\begin{array}{l}3 \\
6482 \\
U_{M L}^{*}\end{array}$ & $\begin{array}{l}5 b \\
80271 \\
\text { UML }\end{array}$ & $\begin{array}{l}6 \mathrm{~b} \\
80143 \mathrm{~B} \\
\mathrm{UML}\end{array}$ & $\begin{array}{l}8 \mathrm{~b} \\
66216 \\
\text { UML* }\end{array}$ & $\begin{array}{l}10 a \\
80144 C \\
\text { UML }\end{array}$ & $\begin{array}{l}10 \mathrm{~b} \\
80146 \mathrm{~A} \\
\text { UML }\end{array}$ & $\begin{array}{l}10 c \\
80146 B \\
\text { UML }\end{array}$ & $\begin{array}{l}12 \\
80144 \mathrm{~A} \\
M\end{array}$ & $\begin{array}{l}13 \\
80146 \mathrm{C} \\
M\end{array}$ & $\begin{array}{l}15 \\
80142 \\
M\end{array}$ \\
\hline $\mathrm{SiO}_{2}$ & 33.0 & 33.46 & 32.62 & 31.61 & 32.37 & 32.52 & 32.57 & 32.07 & 31.66 & 31.44 \\
\hline $\mathrm{FeO}$ & 42.45 & 45.26 & 53.75 & 54.25 & 54.14 & 54.32 & 53.51 & 57.66 & 59.60 & 60.21 \\
\hline MnO & 0.51 & 0.59 & 0.97 & 0.82 & 1.00 & 0.97 & 1.09 & 0.90 & 0.77 & 1.02 \\
\hline $\mathrm{MgO}$ & 23.79 & 20.68 & 13.21 & 12.47 & 12.18 & 12.40 & 12.86 & 9.30 & 8.33 & 8.12 \\
\hline Total & 99.75 & 99.99 & 100.15 & 99.15 & 99.69 & 100.21 & 100.03 & 99.93 & 100.36 & 100.79 \\
\hline \multicolumn{11}{|c|}{ Unit cell content on the basis of 4 oxygens: } \\
\hline $\mathrm{Si}$ & 0.961 & 0.983 & 0.996 & 0.989 & 1.002 & 1.001 & 0.997 & 1.008 & 1.003 & 0.996 \\
\hline $\mathrm{Fe}$ & 1.034 & 1.112 & 1.373 & 1.419 & 1.402 & 1.398 & 1.370 & 1.516 & 1.579 & 1.595 \\
\hline Mn & 0.126 & 0.015 & 0.025 & 0.022 & 0.026 & 0.025 & 0.028 & 0.024 & 0.021 & 0.028 \\
\hline $\mathrm{Mg}$ & 1.032 & 0.906 & 0.602 & 0.582 & 0.562 & 0.569 & 0.587 & 0.436 & 0.393 & 0.383 \\
\hline Fo & 50.0 & 44.6 & 30.5 & 29.1 & 28.3 & 28.5 & 29.6 & 22.1 & 19.7 & 19.1 \\
\hline
\end{tabular}

$\mathrm{UML}=$ ultramafic layer; $\mathrm{M}=$ mangeritic layer.

*From Duchesne (1972b).

In the Creigh diagram (Fig. 6) the UML associated with the mangerites are somewhat richer in $\mathrm{SiO}_{2}$ and poorer in mafics than those associated with the norites. Similarly, the mangerites define a more or less linear array richer in $\mathrm{SiO}_{2}$ than the norites. The chemical evolution with the structural height in the UML is thus parallel to that of the associated $\mathrm{SiO}_{2}$-rich rocks.

Partitioning of $\mathrm{P}_{2} \mathrm{O}_{5}$ between UML and the associated norites or mangerites is not important; the concentration ratios between UML and norites and ULM and mangerites are $1.15 \pm 0.28$ and 1.21 
TABLE 4

Chemical composition of clinopyroxenes (microprobe analyses)

\begin{tabular}{|c|c|c|c|c|c|c|c|c|c|}
\hline & \multicolumn{2}{|c|}{ Noritic Transition Zone } & \multicolumn{7}{|c|}{ Mangeritic Transition Zone } \\
\hline & $\begin{array}{l}1 \\
80231 \\
N\end{array}$ & $\begin{array}{l}5 \mathrm{~b} \\
80271 \\
\text { UML }\end{array}$ & $\begin{array}{l}6 \mathrm{~b} \\
80143 \mathrm{~B} \\
\text { UML }\end{array}$ & $\begin{array}{l}8 \mathrm{~b} \\
66216 \\
\mathrm{UML}^{*}\end{array}$ & $\begin{array}{l}10 \mathrm{a} \\
80144 \mathrm{C} \\
\text { UML }\end{array}$ & $\begin{array}{l}10 \mathrm{~b} \\
80146 \mathrm{~A} \\
\text { UML }\end{array}$ & $\begin{array}{l}12 \\
80144 A \\
M\end{array}$ & $\begin{array}{l}13 \\
80146 \mathrm{C} \\
\mathrm{M}\end{array}$ & $\begin{array}{l}15 \\
80142 \\
M\end{array}$ \\
\hline $\mathrm{SiO}_{2}$ & 50.17 & 49.54 & 49.64 & 49.99 & 49.97 & 49.28 & 50.25 & 49.26 & 49.92 \\
\hline $\mathrm{TiO}_{2}$ & 0.37 & 0.49 & 0.51 & 0.57 & 0.43 & 0.50 & 0.43 & 0.39 & 0.40 \\
\hline $\mathrm{Al}_{2} \mathrm{O}_{3}$ & 2.03 & 2.29 & 2.05 & 2.16 & 1.97 & 2.28 & 1.77 & 1.34 & 1.49 \\
\hline $\mathrm{FeO}_{\mathrm{t}}$ & 10.34 & 11.17 & 16.08 & 16.68 & 15.43 & 14.27 & 16.13 & 18.21 & 19.49 \\
\hline $\mathrm{MnO}$ & 0.27 & 0.25 & 0.47 & 0.32 & 0.39 & 0.29 & 0.43 & 0.37 & 0.46 \\
\hline $\mathrm{MgO}$ & 12.83 & 12.65 & 10.38 & 9.81 & 9.97 & 9.86 & 9.02 & 8.13 & 8.76 \\
\hline $\mathrm{CaO}$ & 21.38 & 20.37 & 19.56 & 20.35 & 20.38 & 21.33 & 20.80 & 20.31 & 19.37 \\
\hline $\mathrm{Na}_{2} \mathrm{O}$ & 0.44 & 0.51 & 0.63 & & 0.60 & 0.57 & 0.90 & 0.50 & 0.50 \\
\hline Total & 97.83 & 97.27 & 99.32 & 99.88 & 99.14 & 98.38 & 99.73 & 98.61 & 100.39 \\
\hline \multicolumn{10}{|c|}{ Unit cell content on the basis of 4 cations and 12 charges: } \\
\hline $\mathrm{Si}$ & 1.918 & 1.908 & 1.910 & 1.930 & 1.927 & 1.910 & 1.933 & 1.939 & 1.930 \\
\hline $\mathrm{Al}^{\mathrm{IV}}$ & 0.082 & 0.092 & 0.089 & 0.070 & 0.073 & 0.090 & 0.067 & 0.061 & 0.068 \\
\hline $\mathrm{Al}^{\mathrm{VI}}$ & 0.010 & 0.012 & 0.003 & 0.028 & 0.017 & 0.015 & 0.013 & 0.014 & 0.000 \\
\hline $\mathrm{Ti}$ & 0.011 & 0.014 & 0.015 & 0.017 & 0.012 & 0.015 & 0.013 & 0.012 & 0.012 \\
\hline $\mathrm{Fe}^{3+}$ & 0.083 & 0.089 & 0.104 & 0.009 & 0.076 & 0.089 & 0.096 & 0.074 & 0.086 \\
\hline $\mathrm{Fe}^{2+}$ & 0.248 & 0.271 & 0.414 & 0.530 & 0.422 & 0.374 & 0.423 & 0.528 & 0.544 \\
\hline $\mathrm{Mn}$ & 0.009 & 0.008 & 0.015 & 0.010 & 0.013 & 0.010 & 0.014 & 0.012 & 0.015 \\
\hline $\mathrm{Mg}$ & 0.731 & 0.726 & 0.596 & 0.565 & 0.573 & 0.570 & 0.517 & 0.477 & 0.505 \\
\hline $\mathrm{Ca}$ & 0.876 & 0.841 & 0.807 & 0.842 & 0.842 & 0.886 & 0.857 & 0.857 & 0.802 \\
\hline $\mathrm{Na}$ & 0.033 & 0.038 & 0.047 & 0.000 & 0.045 & 0.043 & 0.067 & 0.038 & 0.037 \\
\hline $\mathrm{Mg}$ & 37.7 & 37.7 & 31.0 & 29.0 & 30.0 & 29.7 & 27.3 & 24.6 & 26.1 \\
\hline $\mathrm{Fe}$ & 17.1 & 18.7 & 27.0 & 27.7 & 26.0 & 24.1 & 27.4 & 31.1 & 32.5 \\
\hline $\mathrm{Ca}$ & 45.2 & 43.6 & 42.0 & 43.3 & 44.0 & 46.2 & 45.3 & 44.3 & 41.4 \\
\hline
\end{tabular}

$\mathrm{N}=$ noritic layer $; \mathrm{UML}=$ ultramafic layer $\mathrm{M}=$ mangeritic layer.

*From Duchesne (1972b).

TABLE 5

Chemical composition of Ti-magnetites of the UML (mictoprobe analyses)

\begin{tabular}{|c|c|c|c|c|c|c|c|}
\hline & $\begin{array}{l}3 \\
6482\end{array}$ & $\begin{array}{l}5 \mathrm{~b} \\
80271\end{array}$ & $\begin{array}{l}6 a \\
80143 b\end{array}$ & $\begin{array}{l}8 b \\
66216\end{array}$ & $\begin{array}{l}10 \mathrm{a} \\
80144 \mathrm{C}\end{array}$ & $\begin{array}{l}10 \mathrm{~b} \\
80146 \mathrm{~A}\end{array}$ & $\begin{array}{l}10 \mathrm{C} \\
80146 \mathrm{~B}\end{array}$ \\
\hline $\mathrm{FeO}_{\mathrm{t}}$ & 78.4 & 81.39 & 75.25 & 72.0 & 74.82 & 70.40 & 71.37 \\
\hline $\mathrm{FeO}_{\text {calc }}$ & 33.7 & 33.69 & 35.84 & 36.7 & 36.40 & 36.82 & 37.08 \\
\hline $\mathrm{MnO}$ & 0.22 & 0.29 & 0.43 & 0.57 & 0.51 & 0.59 & 0.48 \\
\hline $\mathrm{MgO}$ & 0.90 & 0.31 & 0.31 & 0.63 & 0.20 & 0.33 & 0.31 \\
\hline $\mathrm{CaO}$ & 0.16 & 0.03 & * & 0.16 & 0.02 & 0.02 & * \\
\hline $\mathrm{ZnO}$ & 0.21 & & & 0.21 & & & \\
\hline $\mathrm{Fe}_{2} \mathrm{O}_{3}$ calc & 49.7 & 53.00 & 43.79 & 39.2 & 42.70 & 37.31 & 38.10 \\
\hline $\mathrm{V}_{2} \mathrm{O}_{3}$ & 0.21 & & & 0.04 & & & \\
\hline $\mathrm{Al}_{2} \mathrm{O}_{3}$ & 2.1 & 3.49 & 4.67 & 1.4 & 4.34 & 4.08 & 3.56 \\
\hline $\mathrm{TiO}_{2}$ & 10.9 & 9.09 & 15.29 & 19.2 & 16.54 & 20.40 & 20.29 \\
\hline $\mathrm{SiO}_{2}$ & 1.2 & 0.08 & 0.07 & 1.5 & 0.13 & 0.03 & 0.19 \\
\hline Total & 99.4 & 97.97 & 100.40 & 99.8 & 100.84 & 99.58 & 100.01 \\
\hline
\end{tabular}

Except 3 and $8 \mathrm{~b}$ (from Duchesne, 1970, 1972a) which were determined on separated mineral fractions, allowing direct determination of $\mathrm{FeO}$ by titration, all analyses were made by microprobe (using a defocused beam to average the cloth-microtextured grains), and $\mathrm{FeO}, \mathrm{Fe}_{2} \mathrm{O}_{3}$ and the total were recalculated on an ilmenite-magnetite basis, all ulvöspinel being oxidized subsolvus (see Duchesne, 1970).

*Below detection limit. 


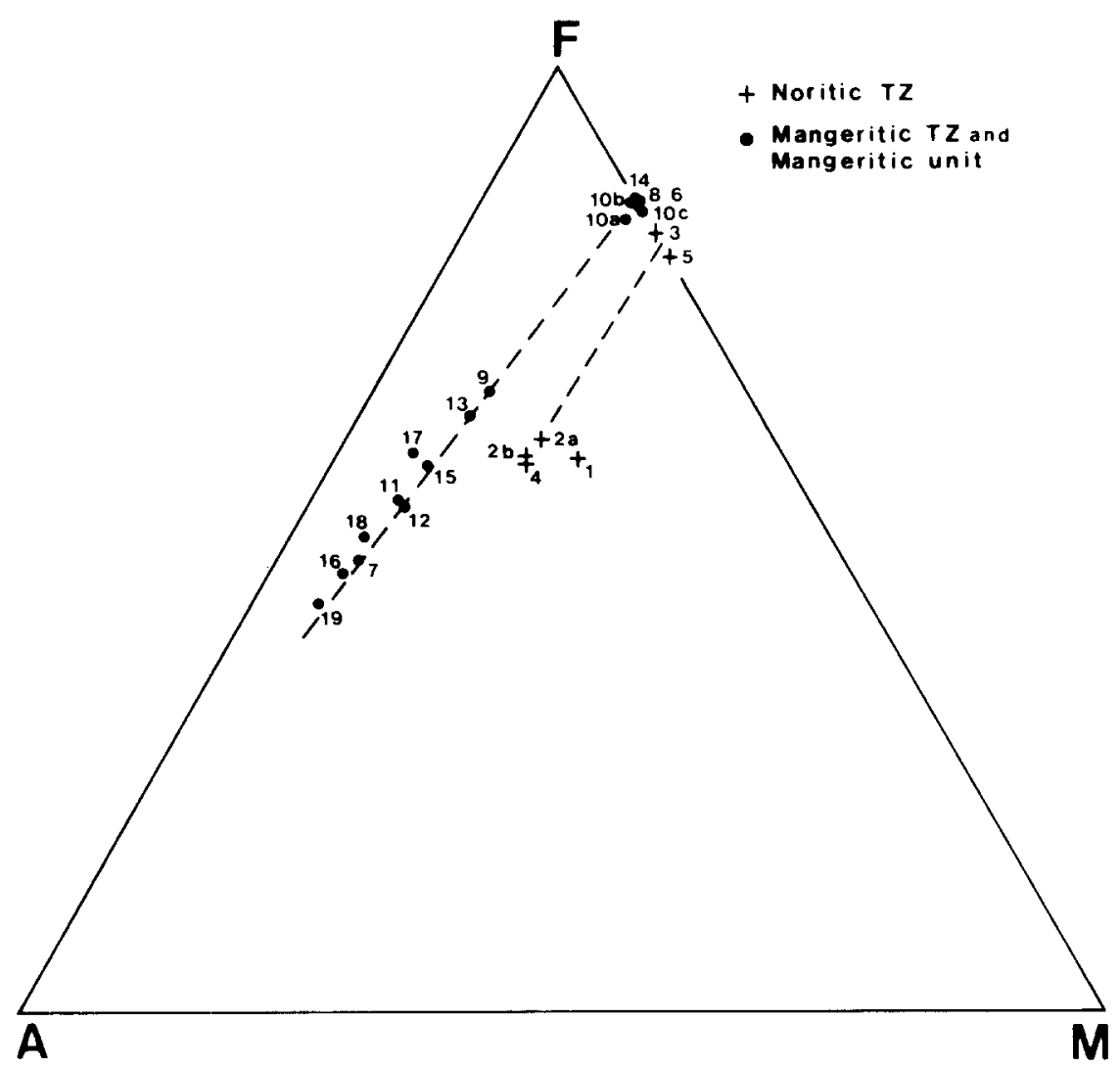

Fig. 5. $\mathrm{Na}_{2} \mathrm{O}+\mathrm{K}_{2} \mathrm{O}(A)-\mathrm{FeO}+0.9 \mathrm{Fe}_{2} \mathrm{O}_{3}(F)-\mathrm{MgO}(M)$ diagram. (crosses) noritic Transition Zone; (solid circles) mangeritic Transition Zone and mangeritic unit. The numbers refer to analysis number in Tables 1 and 2 and Fig. 3. The dashed line joins the UML to associated norites and mangerites.

\pm 0.2 , respectively. $\mathrm{Sc}, \mathrm{Zn}$ and $\mathrm{Co}$ are enriched in the UML by factors of 1.6 to $4.5 . \mathrm{Zr}$ is also enriched in the UML relative to the associated norites by a factor of 3 , but the inverse situation holds for the UML associated with the mangerites: mangerites are enriched by a factor of 2 . The rare earth elements (REE) (Fig. 7) are somewhat lower in the UML than in the associated $\mathrm{SiO}_{2}$-richer rock: 1.4 to 2 times for $\mathrm{La} ; 1.1$ to 1.3 times for $\mathrm{Nd} ; 1.1$ to 1.5 times for $\mathrm{Yb} ; 1.14 \pm 0.15$ times for $\mathrm{Y}$. $\mathrm{Ba}$ and $\mathrm{Rb}$ follow $\mathrm{K}$ and are therefore enriched in the more $\mathrm{SiO}_{2}$-rich rocks.

The REE distribution (Fig. 7) shows that the mangerites from the Transition Zone have distinct positive $\mathrm{Eu}$ anomalies, thus confirming previous results obtained on the mangeritic unit (Demaiffe et al., 1979; Wiebe, 1984). On the other hand, the UML show only very minor positive or negative Eu anomalies.

\section{Discussion}

\section{Petrographic texture}

The interpretation of the textural relationships in terms of order of crystallization is the following. In the UML olivine and apatite were the first minerals to crystallize; cpx appeared later in the noritic Transition Zone but crystallized simultaneously with the olivine in the mangeritic Transition Zone; Fe-Ti oxides minerals and the small quantity of feldspars were the last to complete their crystallization. In the mangerites mesoperthite crystals formed before the crystallization of the groundmass, which started with the simultaneous crystallization of the two feldspars and possibly part of the mafic minerals, and ended with the interstitial growth of the rest of the mafics. The larger crystals of apatite could have been contemporaneous with the mesoperthites. 


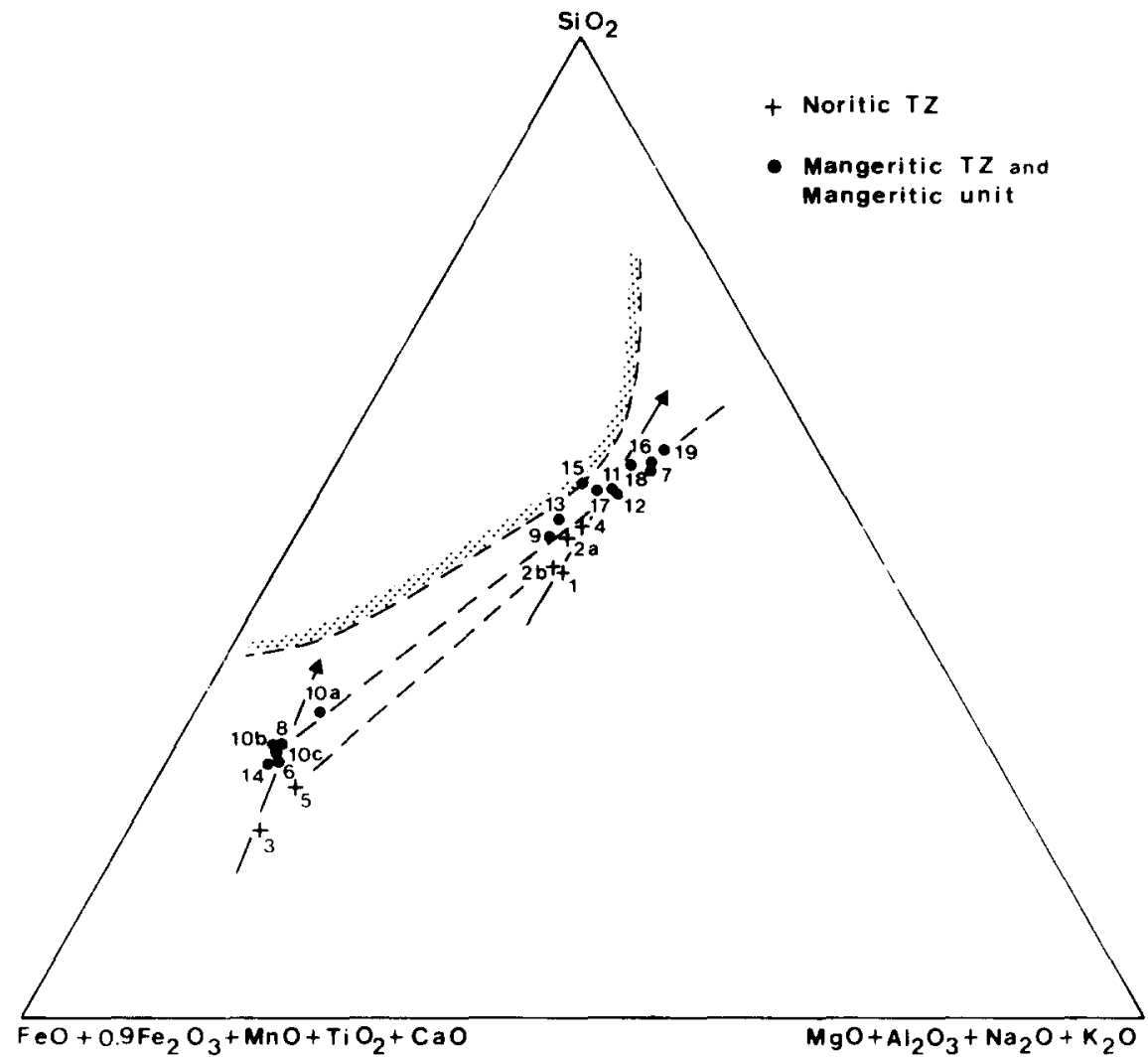

Fig. 6. Creigh diagran as modified by Philpotts (1981). Same symbols as in Fig. 4 . The boundary of the immiscibility field after Freestone (1978) is also shown. The arrows indicate the evolution with decreasing temperature and increasing structural height.

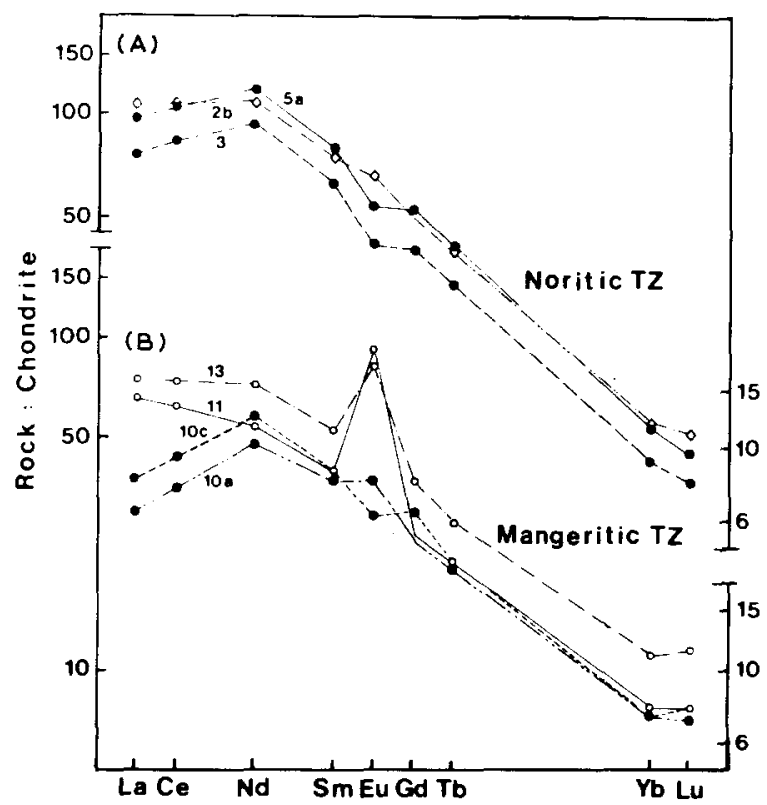

Fig. 7. Chondrite-normalized REE distributions: $(A)$ noritic Transition Zone: solid circles $=$ UML; open diamonds $=$ associated norites. $(B)$ mangeritic Transition Zone: solid circles = UML; open circles = associated mangerites. The numbers refer to data in Table 2. 
In the classical crystal settling interpretation for the formation of cumulate rocks (see Wager and Brown, 1968), mangerites would result from the accumulation of mesoperthite and some apatite crystals, and the groundmass from the crystallization of interstitial liquid. In the UML of the noritic Transition Zone olivine crystals and the apatite grains isolated between the olivines are the only phases with the characteristic euhedral habit of cumulus minerals. These features, however, vanish in UML of the mangeritic Transition Zone, where apatite mainly occurs as inclusions in cpx (more rarely in olivine) and olivine shows co-crystallization habits with cpx. In all rock types, cpx, Fe-Ti oxides and fine-grained apatite owe their final shapes to postcumulus growth. Complete elimination of feldspar from most UML is probably caused by compositional convection of the light interstitial liquid within the pore space of the mineral pile (Sparks et al., 1985). The absence of zoning and the interlobate grain boundaries can also be accounted for by adcumulus growth. It thus appears that adcumulus growth played such an important role that many, if not all, indications of accumulation have been blurred, especially in the UML of the mangeritic Transition Zone. A cumulate model is therefore not much supported by petrographic evidence and, as an alternative, formation of the UML through closed-system crystallization of an ultramafic liquid should be considered. This implies the existence of two liquids, one giving rise to the ultramafic rocks and the other to the norites and mangerites. Chemical data shed some light on this question.

\section{Immiscibility}

The formation of two liquids of contrasting composition through immiscibility has been advocated for a number of natural occurrences within the range of compositions studied here (Roedder, 1979; Wiebe, 1979; Philpotts, 1981). Immiscibility finds support in the experimental work of Ryerson and Hess (1978), who demonstrated the existence of ferropyroxenitic liquids and pointed to the crucial role of $\mathrm{P}_{2} \mathrm{O}_{5}$.

In the pseudo-ternary diagram of Fig. 6 the analyses plot not far from the experimental solvus of Freestone (1978). Inasmuch as the position of the solvus is known to be sensitive to small chemical variations, the position of the samples does not contradict an immiscibility process. However, several other features argue against such a model:

(1) Olivine, which is the first mineral to crystallize in the UML of the noritic Transition Zone, is absent from the associated norites. This is inconsistent with phase equilibria considerations, which require identical liquidus minerals in both liquids, at least at the onset of crystallization.

(2) $\mathrm{P}_{2} \mathrm{O}_{5}$ is not enriched in the UML to the extent predicted by experimental work. Enrichment factors of 10 (for low $\mathrm{P}_{2} \mathrm{O}_{5}$ compositions) and of 24 (for high $\mathrm{P}_{2} \mathrm{O}_{5}$ ) have been obtained by Watson (1976) and Ryerson and Hess (1978), respectively. These values are an order of magnitude higher than those reported here $(1.1-1.2)$.

(3) The REE are enriched in the silica-rich rock relative to the mafic rocks. This is opposite to what can be predicted on the basis of the degree of polymerization of the melts and the complexing properties of phosphorus. The same inversion is also observed for $\mathrm{Ba}$, which is strongly concentrated in the silicarich rocks.

(4) If immiscibility were the controlling mechanism, the chemical evolution with decreasing temperature (i.e. with the increase in structural height) in the UML and associated norites and mangerites should diverge on the boundary of the immiscibility field (Fig. 5), the Fe-rich liquid becoming richer in $\mathrm{Fe}$ while the associated liquids evolve towards more silica-rich compositions. Instead, the two evolutions are parallel. It thus appears that geochemical constraints lead to rejection of an immiscibility hypothesis.

\section{Crystal sorting}

As already mentioned, the mangerites in the Transition Zone and higher in the sequence, i.e. in the mangeritic unit, are characterized by a constant $F / M$ ratio in the $A F M$ diagram. At first sight this feature, which might be called a Bowen trend at high $\mathrm{Fe} /(\mathrm{Fe}+\mathrm{Mg})$ ratio, appears paradoxical for fractional crystallization processes. Indeed, judging from the stratigraphic evidence, the various rocks are forming a succession of decreasing temperature, which dictates a gradual increase in the $\mathrm{Fe} /(\mathrm{Fe}+\mathrm{Mg})$ ratio of the liquidus mafic minerals. This is actually the case, since all minerals in the sequence display gradual composition changes (e.g., olivine from $\mathrm{Fo}_{30}$ to $\mathrm{Fo}_{19}$ in the mangeritic Transi- 
tion Zone; Ti-magnetite from $15 \% \mathrm{TiO}_{2}$ to $20 \%$ $\mathrm{TiO}_{2}$ in the UML). But because of a minor change in the mineral proportions (Table 6), the $\mathrm{Fe}$ increase in olivine and $\mathrm{cpx}$ is exactly balanced by the $\mathrm{Fe}$ decrease in Ti-magnetite. The increase in the $\mathrm{Fe} /$ $(\mathrm{Fe}+\mathrm{Mg})$ ratio of the bulk cumulate of mafic minerals is thus blocked in the mangeritic Transition Zone. In other words, the bulk distribution coefficient of $\mathrm{Fe} /(\mathrm{Fe}+\mathrm{Mg})$ between the cumulate and the liquid is equal to unity. As a consequence, the liquid line of descent coincides with the evolution of the cumulates in the $A F M$ diagram. Least-squares regression calculations showed that the linear relationship that appears on the $A F M$ diagram holds for all other elements. The mangerites can indeed be considered as mixtures of various proportions of a feldspathic component, some apatite and a mafic component of the average composition of the UML of the mangeritic Transition Zone.

This conclusion can be related to the porphyritic texture of the mangeritic rocks, which shows phenocrysts of mesoperthite and large apatite crystals contained in a groundmass representing the associated residual melt. This interpretation is corroborated by the positive europium anomaly of the mangerites.

From all these interlocking evidences it can be concluded that the minerals from the UML of the mangeritic Transition Zone, together with mesoperthite and some apatite, represent cumulus minerals in equilibrium with a melt with the composition of the groundmass. Strong crystal sorting and postcumulus processes are responsible for the drastic separation of the mafics - which now constitute the UML - from the mesoperthites, now contained in the mangerites. As for apatite in the mangeritic layers, the larger crystals would be liquidus minerals, while the small ones essentially result from crystallization of the intercumulus liquid. The variation in the feldspar content of the mangerites from layer to layer is due to variable proportions of this trapped intercumulus liquid.

\section{Origin of the layering}

The concept of sedimentation of minerals in a magma due to differences in density (Wager and Brown, 1968) has been seriously questioned on theoretical grounds. Calculated densities for plagioclases and melts indicate that most if not all plagioclases would have floated rather than settled in the conditions pertaining during the differentiation of basaltic layered bodies (Campbell et al., 1978; McBirney and Noyes, 1979; Morse, 1979; Kushiro, 1980; Irvine, 1982). Instead of a crystallization in the melt followed by the settling or flotation of the minerals to form a cumulate, "in situ" crystallization processes have been suggested (McBirney and Noyes, 1979). Morse (1979) revived Wager's (1959) hypothesis of "oscillatory nucleation" to crystallize and "accumulate" feldspars on the floor of a magma chamber. This mechanism, in which density difference only plays a minor role, is able to account

\section{TABLE 6}

Calculated mineral content (in wt.\%) of the UML

\begin{tabular}{|c|c|c|c|c|c|c|c|}
\hline & \multicolumn{2}{|c|}{ Noritic Transition Zone } & \multicolumn{5}{|c|}{ Mangeritic Transition Zone } \\
\hline & $\begin{array}{l}3 \\
6482 * 1\end{array}$ & $\begin{array}{l}5 \mathrm{a} \\
80147 \mathrm{~B}^{* 2}\end{array}$ & $\begin{array}{l}6 \\
6484 * 3\end{array}$ & $\begin{array}{l}8 \\
80145 C^{* 4}\end{array}$ & $\begin{array}{l}10 \mathrm{a} \\
80144 \mathrm{C}^{* 5}\end{array}$ & $\begin{array}{l}10 \mathrm{~b} \\
80146 \mathrm{~A}\end{array}$ & $\begin{array}{l}10 \mathrm{c} \\
80146 \mathrm{~B}\end{array}$ \\
\hline Olivine & 36 & 54 & 50 & 47 & 42 & 48 & 52 \\
\hline Clinopyroxene & 12 & 1 & 20 & 24 & 24 & 22 & 17 \\
\hline Ilmenite & 17 & 15 & 6 & 6 & 7 & 5 & 4 \\
\hline Ti-magnetite & 30 & 20 & 22 & 20 & 16 & 21 & 24 \\
\hline Apatite & 5 & 10 & 2 & 3 & 3 & 4 & 3 \\
\hline Mesoperthite & & & & & 8 & & \\
\hline Sum of $r^{2}(* 6)$ & 1.1 & 1.8 & 0.5 & 0.05 & 0.08 & 0.28 & 0.02 \\
\hline
\end{tabular}

The proportions of the various minerals (the composition of which are given in Tables 3 to 5 ), which constitute a rock of a given composition (see Table 1), are determined by least-squares regression calculation. The chemical elements taken into consideration are $\mathrm{SiO}_{2}, \mathrm{TiO}_{2}, \mathrm{Al}_{2} \mathrm{O}_{3}, \mathrm{FeO}_{t}, \mathrm{MgO}, \mathrm{CaO}$ and $\mathrm{P}_{2} \mathrm{O}_{5}$, except in $10 \mathrm{a}$, where $\mathrm{Na}_{2} \mathrm{O}$ and $\mathrm{K}_{2} \mathrm{O}$ are also considered.

${ }^{* 1} \mathrm{Cpx}$ from neighbouring rock $1(80231) ; *^{2}$ All minerals from $5 \mathrm{~b}(80271) ;{ }^{* 3}$ All minerals from $6 \mathrm{a}$ (80143B); ${ }^{* 4}$ All minerals from $8 \mathrm{~b}$ (66216); ${ }^{* 5}$ Mesoperthite $\mathrm{Or}_{45} \mathrm{Ab}_{48} \mathrm{An}$, separated from 19 (TII) and analysed (Duchesne, 1972a); ${ }^{* 6}$ Sum of squared residues. 


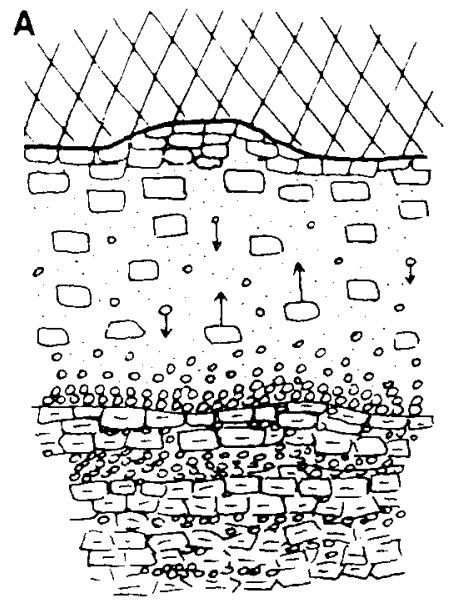

\section{Enveiope}

Residual

magma

NoriticTZ

Norite

B

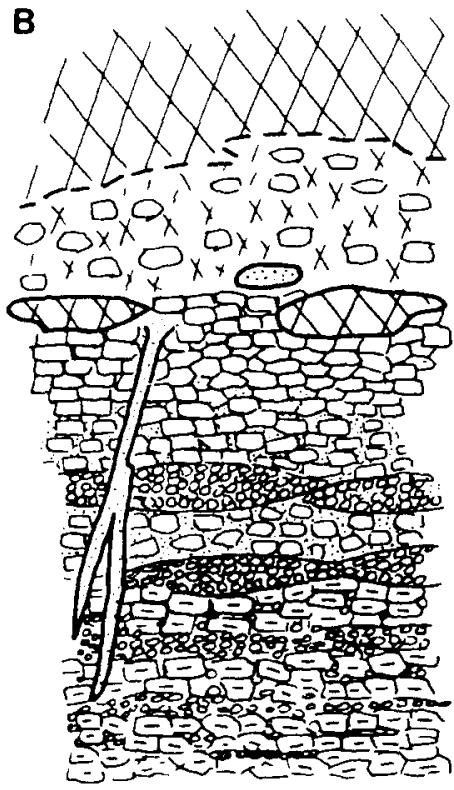

for the upward sense of crystallization (from bottom to top of the chamber) and for the virtual absence of flotation cumulates. Judging from the abundant evidence of layered structures in the lower part of BKSK, this process may well have been operative in that part of the massif. However, since fractional crystallization increases the Fe content of the melt and consequently its density (Bottinga and Weill, 1972), the density differences between the feldspars and the melt can reach a critical value above which the feldspars can no longer remain on the floor and start floating.

We believe that this critical value was reached in the mangeritic Transition Zone. Mesoperthite, having a density of 2.613 at room temperature (Morse, 1979), is less dense than plagioclase (2.63-2.76) and is able to start floating while olivine $\left(\mathrm{Fo}_{30}-\right.$ $\mathrm{Fo}_{10}: 4.0-4.2$ ), cpx (ferroaugite: $3.5-3.6$ ), ilmenite (4.7) and Ti-magnetite (5.0-5.2) are sinking. The abundant crystallization of high-density iron-rich minerals in the Transition Zone must have changed the evolution of the density of the residual melt, causing it to pass through a maximum and then decrease (Huppert and Sparks, 1984), the "tholeiitic" trend which characterizes the evolution in the lower part of BKSK being replaced by a "calcalkaline" trend. The fractionation trend of individual minerals (e.g., olivine) indicates that the temperature was decreasing towards the roof of the intrusion. As shown by McBirney (1980), a situation of this kind is favourable to the formation of a vertical zonation in the chemical composition of the magma, which would not be disturbed by the rising mesoperthite phenocrysts. The magma would thus have become stratified from the base of the mangeritic Transition Zone up to the roof of the intrusion.

A double diffusive convection (Huppert and Sparks, 1984) can be invoked to account for the succession of pairs of ultramafic and mangeritic

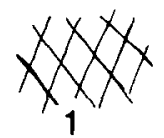

2

$$
\begin{aligned}
& x \times x x \\
& x \times x x \\
& 3
\end{aligned}
$$

\section{Norite}

456

Fig. 8. Schematic representation of the evolution of the magma chamber in its later stages. Legend: $1=$ metamorphic envelope and xenoliths; 2 = residual liquids; $3=$ acidic material, possibly formed through in situ melting of the envelope; $4=$ mesoperthite crystals; $5=$ plagioclase crystals; $6=$ mafic minerals (olivine, pyroxenes, Fe-Ti oxide minerals).

A. Situation at the beginning of the mangeritic Transition Zone. Mesoperthite and mafic minerals crystallize in the residual liquid remaining after the formation of the noritic Transition Zone. Mesoperthite floats and accumulates at the roof while mafics sink to form UML.

B. Complete consolidation gives rise to the observed sequence of rocks. Residual liquids occur as groundmass material in the mangerites from the mangeritic Transition Zone, as dykes cutting across the mangerites (Örsland dyke) or as pillow-like inclusions in the quartz mangerites. Note that the original position of the roof has been modified through melting and/or intrusion of quartz mangerite. It is not excluded that some residual liquids may have mixed with the quartz mangeritic magma. The lower part of the magma chamber, containing anorthosites, leuconorites and norites in megarhythmic units, is not represented. 
layers, despite the restrictions of McBirney (1985). The vertical zonation could have evolved into a series of magma layers, each one producing a UML by settling of the mafic minerals in its lower part, under a mush of floating mesoperthite and residual melt, representing a mangerite layer.

\section{Origin of the mangeritic unit}

The model proposed here for the formation of the mangeritic layers of the Transition Zone is at variance with previous interpretations of Duchesne (1978) and Demaiffe et al. (1979), who interpreted the mangerites as "normal" cumulates formed in equilibrium with the overlying quartz mangeritic liquid. The present data suggest that the mangeritic unit is also a flotation cumulate. This interpretation in turn implies that the roof of the intrusion was originally situated near or at the contact with the quartz mangerites of the upper part, in the zone now girdled with xenolithic material (Fig. 8). This raises other questions: where are the residual liquids of the differentiation and what is the origin of the quartz mangerites? If the mangeritic unit actually formed at the top of the magma chamber it must have largely prevented the escape of residual liquids which either remained trapped in the magma chamber as an interstitial component of the cumulates, or cut across the already solidified mangerites as dykes. We believe that the fine-grained monzonitic groundmass of the mangerites in the Transition Zone and the Örsland dyke (Figs. 2 and 8) are likely to represent such liquids.

As for the quartz mangerites, several scenarios are plausible. They may be formed by in situ melting of the envelope or, as suggested by Wiebe (1984), might represent a different intrusion of anatectic melts. Contamination with residual liquids of BKSK cannot be ruled out. As already mentioned the quartz mangeritic unit is petrographically heterogeneous and as yet insufficiently known in detail to allow firm conclusions.

\section{Conclusions}

Rapid and continuous evolution in the composition of mafic minerals (olivine: from $\mathrm{Fo}_{50}$ to $\mathrm{Fo}_{19}$; cpx: from $\mathrm{Ca}_{45} \mathrm{Fe}_{17} \mathrm{Mg}_{38}$ to $\mathrm{Ca}_{42} \mathrm{Fe}_{32} \mathrm{Mg}_{26}$; Ti-magnetite: from $10 \%$ to $20 \% \mathrm{TiO}_{2}$ ) in a few tens of meters characterizes the Bakka-Örsland transition, between the norites which terminate the lower part of the massif and the mangerites which mark the beginning of the acidic upper part of BKSK.

Due to complementary chemical evolution of the various mafic minerals, the bulk composition of the mafic minerals has a virtually constant $\mathrm{Fe} /$ $(\mathrm{Fe}+\mathrm{Mg})$ ratio in the upper part of the Transition Zone and in the overlying mangeritic unit. It is therefore in the Transition Zone that the evolution of the liquids towards higher $\mathrm{Fe} / \mathrm{Mg}$ ratio in the $A F M$ diagram (Fenner trend) is replaced by the Bowen trend (enrichment in alkalis and silica) through an abrupt change in direction. Moreover, the Bowen trend here shows a virtually constant $\mathrm{Fe} /(\mathrm{Fe}+\mathrm{Mg})$ ratio, which implies a bulk partition coefficient of $\mathrm{Fe} /(\mathrm{Fe}+\mathrm{Mg})$ between the melt and the solid equal to 1 .

The strong contrast in whole-rock composition between the UML and associated noritic and mangeritic rocks is not due to an immiscibility process. In the noritic Transition Zone the mafic-rich rocks do not have the same liquidus phases as the silicarich rocks, which is inconsistent with the law of equilibrium. The partitioning of $\mathrm{P}_{2} \mathrm{O}_{5}$ and trace elements, particularly the REE and $\mathrm{Ba}$, as well as the parallel evolution of the major elements with decreasing temperature in associated rocks, are opposite to what is expected from experimental evidence and theoretical considerations concerning immiscible liquids derived from a mutual parental liquid.

Accumulation of mafic minerals and adcumulus growth can explain the formation of the UML. Oscillatory nucleation processes provide a satisfactory explanation for the norites and the noritic Transition Zone but require modification when mesoperthite becomes a liquidus mineral. With increasing density contrast between the Fe-rich liquid and the mesoperthite it is likely that the latter started to float in the mangeritic Transition Zone. The porphyritic texture of the rock as well as the strong positive europium anomaly are consistent with such an interpretation. The chemical evolution in the mangeritic transition zone permits the formation of a stratified magma. The layering can be explained by double-diffusive convection.

This opens the way to re-interpretation of the mangeritic unit of the lopolith as a flotation cumulate and to re-assessment of the exact position of the roof of the intrusion. 


\section{Acknowledgements}

Major element chemical analyses were performed in the "Collectif interuniversitaire de géochimie instrumentale" (University of Liège, Director: J.C. Duchesne). Microprobe analyses were made in the "Centre pour l'analyse par microsonde dans les sciences de la Terre" (University of Louvain, Director: D. Laduron). J. Wautier, G. Bologne, G. Delhaze and V. Miocque, as well as an anonymous reviewer, are particularly thanked for their help. This work has been supported by the Belgian FNRS-NFWO and IISN-IIKW.

\section{Appendix - Analytical methods}

Major elements in the rock samples were determined by X-ray fluorescence (XRF) on a CGR Alpha 2020 spectrometer on Li-borate glass dises. $\mathrm{Na}$ and the trace elements reported in Table 1 were also measured by XRF on pressed powder samples, matrix corrections being calculated from the major element composition. FeO was measured by titration.

Instrumental neutron activation (INAA) was used for determination of the trace elements in Table 2. Sample pellets $(800$ to $900 \mathrm{mg}$ ) were irradiated for $7 \mathrm{~h}$ in a neutron flux of ca. $2 \cdot 10^{12} \mathrm{n} \mathrm{cm}^{-2} \mathrm{~s}^{-1}$, and counted with a 75 $\mathrm{cm}^{3} \mathrm{Ge}(\mathrm{Li})$ detector and an extra-high resolution Ge-LEPD (Hertogen and Gijbels, 1971). The samples were analysed relative to secondary in-house standards.

A 4-spectrometer Camebax microprobe was used for the mineral analyses. Matrix corrections were done with the program $Z A F$ of Cameca.

\section{References}

Bottinga, Y, and Weill, D.F., 1972. The viscosity of magmatic silicate liquids, a model for calculation. Am. J. Sci., 272: 438-475.

Buddington, A.F., 1972. Differentiation trends and parental magmas for anorthositic and quartz mangerite series, Adirondacks, New York. Geol. Soc. Am. Mem., 132: $477-488$.

Buddington, A.F. and Lindsley, D.H., 1964. Iron-titanium oxide minerals and synthetic equivalents. J. Petrol., 5: 310-357.

Campbell, I.H., Roeder, P.L. and Dixon, J.M., 1978. Plagioclase buoyancy in basaltic liquids as determined with a centrifuge furnace. Contrib. Mineral. Petrol., 67: 369377.

Demaiffe, D., Duchesne, J.C. and Hertogen, J., 1979. Trace element variations and isotopic composition of charnockitic acidic rocks related to anorthosites (Rogaland S.W. Norway). In: L.H. Ahrens (Editor), Origin and
Distribution of the Elements. Pergamon, Oxford, pp. 417-429.

Duchesne, J.C., 1970. Microtextures of Fe-Ti oxide minerals in the South-Rogaland anorthositic complex (Norway). Ann. Soc. Géol. Belg., 93: 527-544.

Duchesne, J.C., 1972a. Iron-titanium oxide minerals in the Bjerkrem-Sogndal massif, southwestern Norway. J. Petrol., 13: 57-81.

Duchesne, J.C., 1972b. Pyroxènes et olivines dans le massif de Bjerkrem-Sogndal (Norvège méridionale). Contribution à l'étude de la série anorthosite-mangérite. 24th Int. Geol. Congr., Montreal, Que., Sect. 2, pp. 320328.

Duchesne, J.C., 1978. Quantitative modeling of $\mathrm{Sr}, \mathrm{Ca}$, $\mathrm{Rb}$ and $\mathrm{K}$ in the Bjerkrem-Sogndal layered lopolith (S.W. Norway). Contrib. Mineral. Petrol., 66: 175184.

Duchesne, J.C. and Demaiffe, D., 1978. Trace elements and anorthosite genesis. Earth Planet. Sci. Lett., 38: $249-272$.

Duchesne, J.C., Maquil, R, and Demaiffe, D., 1985. The Rogaland anorthosites: facts and speculations. In: $A$. Tobi and J. Touret (Editors), The Deep Proterozoic Crust in the North Atlantic Provinces. NATO Adv. Stud. Inst. C158, Reidel, Dordrecht, pp. 449-476.

Emslie, R.F., 1978. Anorthosite massifs, rapakivi granites, and Late Proterozoic rifting of North America. Precambrian Res., 7: 61-98.

Freestone, I.C., 1978. Liquid immiscibility in alkali-rich magmas. Chem. Geol., 23: 115-123.

Hermans, G.A.E.M., Tobi, A.C., Poorter, R.P.E. and Maijer, C., 1975. The high-grade metamorphic Precambrian of the Sirdal-Örsdal area, Rogaland/Vest-Agder, S.W. Norway. Nor. Geol. Unders., 318: 51-74.

Hertogen, J. and Gijbels, R., 1971. Instrumental neutron activation analysis of rocks with a low-energy photon detector. Anal. Chem. Acta, 56: 61-82.

Huppert, H.E. and Sparks, R.S.J., 1984. Double-diffusive convection due to crystallization in magmas. Annu. Rev. Earth Planet. Sci., 12: 11-37.

Irvine, T.N., 1982. Terminology for layered intrusions. J. Petrol., 23: 127-162.

Krause, H. and Pedall, G., 1980. Fe-Ti mineralizations in the Ana-Sira anorthosite, southern Norway. In: J.H. Siivola (Editor), Metallogeny of the Baltic Shield. Geol. Surv. Finland, 307: 56-83.

Kushiro, 1., 1980. Viscosity, density, and structure of silicate melts at high pressure, and their petrological applications. In: R.B. Hargraves (Editor), Physics of Magmatic Processes. Princeton University Press, Princeton, N.J., pp. 93-120.

Martignole, J., 1974. L'évolution magmatique du complexe de Morin et son apport au problème des anorthosites. Contrib. Mineral. Petrol., 44: 117-137.

McBirney, A.R., 1975. Differentiation of the Skaergaard intrusion. Nature (London), 253: 691-694.

McBirney, A.R., 1980. Mixing and unmixing of magmas. J. Volcanol. Geotherm. Res., 7: 35-71.

McBirney, A.R., 1985. Further considerations of doublediffusive stratification and layering in the Skaergaard intrusion. J. Petrol., 26: 993-1001. 
McBirney, A.R. and Noyes, R.M., 1979. Crystallization and layering of the Skaergaard intrusion. J. Petrol., 20: $487-554$.

Michot, J. and Michot, P., 1969. The problem of the anorthosites. The South Rogaland igneous complex (South Western Norway). In: Y.W. Isachsen (Editor), Origin of the Anorthosites and Related Rocks. N.Y. State Mus. Sci. Serv., Mem., 18: 399-410.

Michot, J. and Pasteels, P., 1969. La variation du rapport $\left({ }^{87} \mathrm{Sr} /{ }^{86} \mathrm{Sr}\right)_{0}$ dans les roches génétiquement associées au magma plagioclasique (Premiers résultats). Ann. Soc. Géol. Belg., 92: 255-262.

Michot, P., 1956. La géologie des zones profondes de l'écorce terrestre. Ann. Soc. Géol. Belg., 80: 19-73.

Michot, P., 1960. La géologie de la catazone: le problème des anorthosites, la palingenèse basique et la tectonique catazonale dans le Rogaland méridional (Norvège méridionale). Nor. Geol. Unders., 212g: 1-54.

Michot, P., 1965. La magma plagioclasique. Geol. Rundsch., 54: $956-976$.

Michot, P., 1969. Geological environment of the anorthosites of South Rogaland, Norway. In: Y.W. Isachsen (Editor), Origin of Anorthosite and Related Rocks. N.Y. State Mus. Sci. Serv., Mem., 18: 411-423.

Morse, S.A., 1979. Kiglapait geochemistry, I: Systematics, sampling, and density. J. Petrol., 20: 555-590.

Pasteels, P., Michot, J. and Lavreau, J., 1970. Le complexe éruptif du Rogaland méridional (Norvège). Signification pétrogénétique de la farsundite et de la mangérite quartzique des unités orientales; arguments géochronologiques et isotopiques. Ann. Soc. Géol. Belg., 93: 453476.

Pasteels, P., Demaiffe, D. and Michot, J., 1979. U-Pb and $\mathrm{Rb}-\mathrm{Sr}$ geochronology of the eastern part of the South Rogaland igneous complex, Southern Norway. Lithos, 12: $199-208$.

Philpotts, A.R., 1966. Origin of the anorthosite-mangerite rocks in southern Quebec. J. Petrol., 7: 1-64.

Philpotts, A.R., 1981. A model for the generation of massiftype anorthosites. Can. Mineral., 19: 233-253.

Powell, R. and Powell, M., 1977. Geothermometry and oxygen fugacity barometry using coexisting iron-titanium oxides: a reappraisal. Mineral. Mag., 41: 257-263.
Rietmeijer, F.J.M., 1979. Pyroxenes from iron-rich igneous rocks in Rogaland, S.W. Norway. Doctorat thesis, Department of Geology, University of Utrecht, Utrecht. Geol. Ultraiectina, No. 21, $341 \mathrm{pp}$.

Roedder, E., 1979. Silicate liquid immiscibility in magmas. In: H.S. Yoder (Editor), The Evolution of the Igneous Rocks: Fiftieth Anniversary Perspectives. Princeton University Press, Princeton, N.J., pp. 15-57.

Roelandts, I. and Duchesne, J.C., 1979. Rare-earth elements in apatite from layered norites and iron-titanium oxide ore-bodies related to anorthosites (Rogaland, S.W. Norway). In: L.H. Ahrens (Editor), Origin and Distribution of the Elements. Pergamon, Oxford, pp. 199212.

Ryerson, F.J. and Hess, P.C., 1978. Implications of liquidliquid distribution coefficients to mineral-liquid partitioning. Geochim. Cosmochim. Acta, 42: 921-932.

Sparks, R.S.J., Huppert, H.E., Kerr, R.C., McKenzie, D.P. and Tait, S.R., 1985. Postcumulus processes in layered intrusions. Geol. Mag., 122: 555-568.

Wager, L.R., 1959. Differing powers of crystal nucleation as a factor producing diversity in layered igneous intrusions. Geol. Mag., 96: 75-80.

Wager, L.R. and Brown, G.M., 1968. Layered igneous rocks. Oliver \& Boyd, London, 588 pp.

Watson, E.B., 1976. Two-liquid partition coefficients: experimental data and geochemical implications. Contrib. Mineral. Petrol., 56: 119-134.

Wiebe, R.A., 1979. Fractionation and liquid immiscibility in an anorthositic pluton of the Nain complex, Labrador. J. Petrol., 20: 239-269.

Wiebe, R.A., 1984. Commingling of magmas in the BjerkremSogndal lopolith (southwest Norway): evidence for the compositions of residual liquids. Lithos, 17: 171-188.

Wielens, J.B.W., Andriessen, P.A.M., Boelrijk, N.A.I.M., Hebeda, E.H., Priem, H.N.A., Verdurmen, E.A.T. and Verschure, R.H., 1981. Isotope geochronology in the high-grade metamorphic Precambrian of Southwestern Norway: new data and reinterpretations. Nor. Geol. Unders., 359: 1-30.

Wilson, J.R. and Larsen, S.B., 1985. Two-dimensional study of a layered intrusion - the Hyllingen Series, Norway. Geol. Mag., 122: 97-124. 